\title{
Water-Yield Relationships of Deficit Irrigated Pepper (Capsicum Annuum L. Demre)
}

\author{
Serhat Ayas 1,a,*

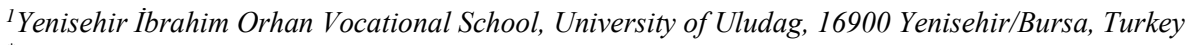

*Corresponding author

\begin{tabular}{|c|c|}
\hline A R T I C LE INFO & A B S T R A C T \\
\hline $\begin{array}{l}\text { Keywords: } \\
\text { Evapotranspiration } \\
\text { Crop yield response factor (ky) } \\
\text { WUE and IWUE values } \\
\text { Yield and quality parameters, } \\
\text { Irrigation planning }\end{array}$ & $\begin{array}{l}\text { This trial was realized in the greenhouses of Uludag University Yenisehir Vocational School } \\
\text { between } 2009 \text { and } 2010 \text { to investigate effects of water deficit on yield and quality parameters of } \\
\text { pepper during four crop growth stages. In this study, fourteen irrigation treatments in four growth } \\
\text { periods (vegetative, flowering, yield formation and ripening) of pepper (Capsicum annuum l. Demre) } \\
\text { were constituted and the yield and quality parameters found from these treatments were evaluated. } \\
\text { The layout of the experiment was a completely randomized block design with three replications for } \\
\text { each of the fourteen irrigation treatments tested. According to the content of the treatments, the } \\
\text { irrigation amount water applied to the plants varied between } 0 \text { and } 744 \mathrm{~mm} \text { in the first year, and } \\
\text { between } 0 \text { and } 750 \mathrm{~mm} \text { in the second year. Water consumption of pepper in the first year ranged } \\
\text { between } 320 \text { and } 760 \mathrm{~mm} \text { and in the second year ranged between } 330 \text { and } 770 \mathrm{~mm} \text {. Yield, fruit } \\
\text { weight, diameter, length and dry matter ratio were determined statistically significant. In } 2009 \text { and } \\
2010 \text { years, the maximum yield were found as } 26.2 \mathrm{t} \mathrm{ha}^{-1} \text { and } 27.8 \mathrm{t} \mathrm{a}^{-1} \text { in } \mathrm{V}_{100} \mathrm{~F}_{100} \mathrm{Y}_{100} \mathrm{R}_{100} \\
\text { treatments, while the minimum yield were found as } 0.2 \mathrm{tha} \mathrm{a}^{-1} \text { and } 0.3 \mathrm{ha}^{-1} \text { in the } \mathrm{V}_{0} \mathrm{~F}_{0} \mathrm{Y}_{0} \mathrm{R}_{0} \text { treatments, } \\
\text { respectively. Water- yield relationship factors (ky) in } 2009 \text { and } 2010 \text { years were found as } 1.29 \text { and } \\
1.24 \text {, respectively. The maximum WUE and IWUE values were obtained from vegetative and } \\
\text { ripening periods. Vegetative and ripening periods may be suggested as the maximum efficient } \\
\text { irrigation periods for the pepper applied with drip irrigation under unheated greenhouse conditions. }\end{array}$ \\
\hline
\end{tabular}

\section{Introduction}

As water demand of growing population continues to rise rapidly and new sources of supply become scarcer, the efficient use of water is increasingly important. As water demand increases in all sectors, ground water is depleted, water ecosystems are polluted, and water resources development is becoming more costly. Since agriculture accounts for $75 \%$ of water consumption in our country, even small improvements in irrigation water use efficiency may contribute significant quantities of water available to further irrigation or to other users (Çakmak and Gökalp, 2011).

Van Straten et al. (2010), stated that protected is worldwide the fastest growing sector of all agricultural production activities. There are two essential causes for this. First, the plants are grown in greenhouse differently from the open field, in this way supplying in a sort of way of abri from the flat-out effect of the exterior air conditions. This allows the production of crops at that specific place. Second, the greenhouse allows to be produced of many crops. Thus, grower allows the farming to come true as desired. It also offers advantages such as higher yield, longer production period, better quality and less use of chemicals. The value added per unit surface area in greenhouse crops is much higher than that in open field.

According to 2017 FAOSTAT; the US, Germany are the United Kingdom are the world's three biggest pepper importers with $1.0,0.4,0.2$ million tons, respectively. Mexico is the largest pepper exporting country with 0.95 million tons. Turkey is one of the significant pepper exporters with Turkey 97312 tons in the world (FAOSTAT, 2017). According to TUIK 2018 data, the pepper production of Bursa province was 163347 tons (Anonymous, 2016).

Pepper as a member of genus Capsicum of Solanaceae family is known as an annual plant in temperate climates and perennial plant in tropical climates. Researchers and botanists acknowledge that the main homeland of pepper is tropical America (Brazil) and spread from there to the 
world. Before America's discovery, pepper was not recognized in other continents, especially in Europe. A limited amount of peppers produced in our country are exported as fresh, pickles, pepper paste, dried or as red chili powder, roasted pepper (Vural et al., 2000).

Sezen (2005) found that surface irrigation is not suggested due to low irrigation efficiency originated from salinity and drainage problems in irrigated areas. From a different viewpoint, traditional irrigation systems where excess water inputs and poor drainage occur, cause environmental problems such as salinity and water logging. In irrigation methods where irrigation water is used efficiently don't have the problems of conventional irrigation methods (Buyukcangaz et al., 2007). Thus, the use of less water consuming irrigation methods is importance with regard to irrigation planning (Anonymous, 2005). The objectives of irrigation planning is to prevent the soil moisture level falling below the critical line for a specific soil and crop condition. This may enable to avoid the harmful effect of water stress by means of estimating the earliest date (Ritchie and Johnson, 1990).

Irrigation planning with drip irrigation relies on approachments connected with evapotranspiration estimations (Bar-Yosef and Sagiv, 1982; McNeeish et al., 1985; Clough et al., 1990; Hartz, 1993) and permissible soil-water depletion (Bogle et al., 1989). Ky represents the declines in the yield as a result of each deficit level in water consumption. $K y$ values usually difficult to create accurately. $K y$ values are affected by regional conditions, soil properties, crop physiology and cultural practices. A suggested $K y$ value for irrigation planning must be high enough to avoid the water stress caused by the needs and specific local situations. It remains low enough for water management (Yuan et al., 2003). Some studies have been realized to investigate the effect of deficient irrigation on pepper (Gencoglan et al., 2006; Sezen et al., 2006; Demirtas and Ayas, 2009). The purposes of this experiment were to obtain a prospectus for pepper growers and to determine drip irrigated pepper response to deficit irrigation regimes in Bursa conditions.

\section{Material and Methods}

The study was realized in Yenisehir Vocational School, Bursa in 2009 and 2010 years. For practical purposes, plastic greenhouse $(8 \mathrm{~m} \times 40 \mathrm{~m})$ was used. In the study place, wintertime's are cold and summertime's are hot. The average annual rainfall and temperature values for the region where the greenhouse experiments were made in 2009 and 2010 were $531.3-804.4 \mathrm{~mm}$ and $13.3-14.6^{\circ} \mathrm{C}$, respectively. While the average minimum temperature for 2009 and 2010 were $-3.6-(5.9)^{\circ} \mathrm{C}$ between January and December, the average maximum temperature in August was measured as 30.6 and $34.6^{\circ} \mathrm{C}$ (Anonymous, 2011a). Maximum and minimum temperature values in greenhouse during the plant growing period (91 days) were $38-38^{\circ} \mathrm{C}$ and $0.9-1.3^{\circ} \mathrm{C}$, respectively in $2009-2010$ years (Figure 1 and 2). The highest and lowest relative humidity values in greenhouse in 2009 and 2010 years were found as 88-87\% and $39-39 \%$, respectively (Figure 3 ). In addition, the highest and lowest radiation values in greenhouse in 20092010 years were measured as 1974-1542 W/m² and 335$139 \mathrm{~W} / \mathrm{m}^{2}$, respectively (Figure 4) (Anonymous, 2011b).

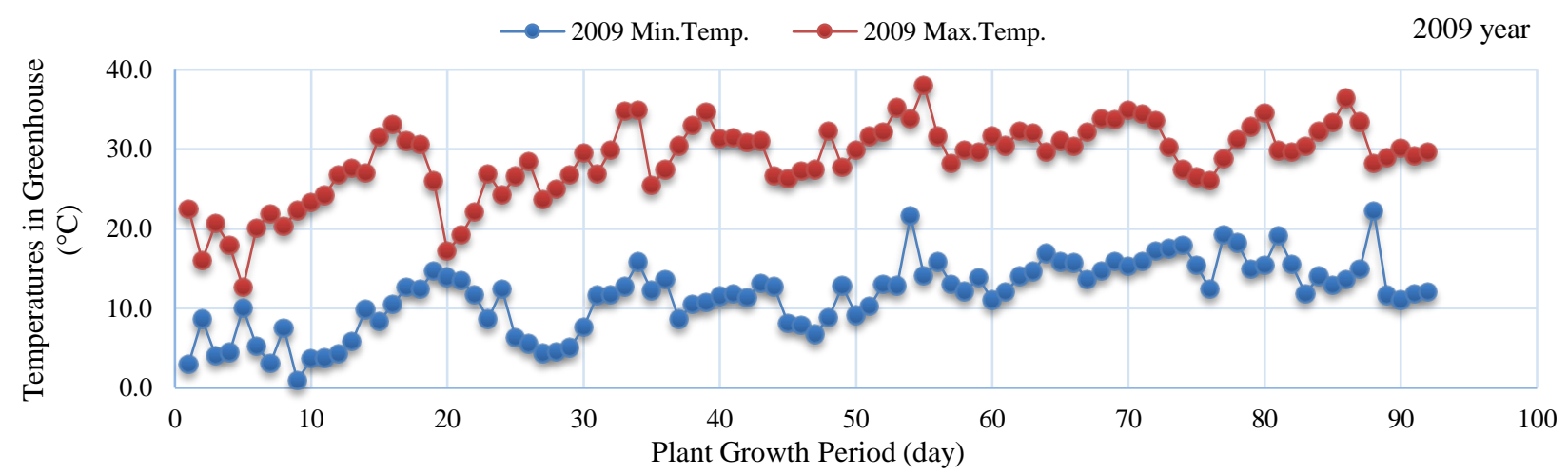

Figure 1 Temperatures in greenhouse during the plant growth period in 2009 year

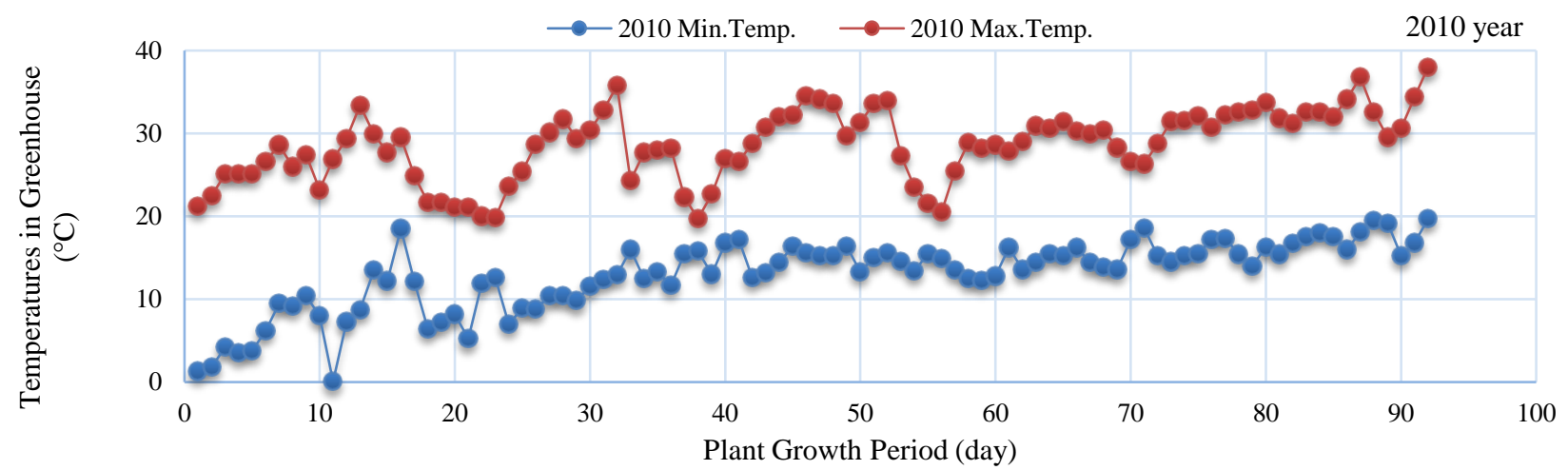

Figure 2 Temperatures in greenhouse during the plant growth period in 2010 year 


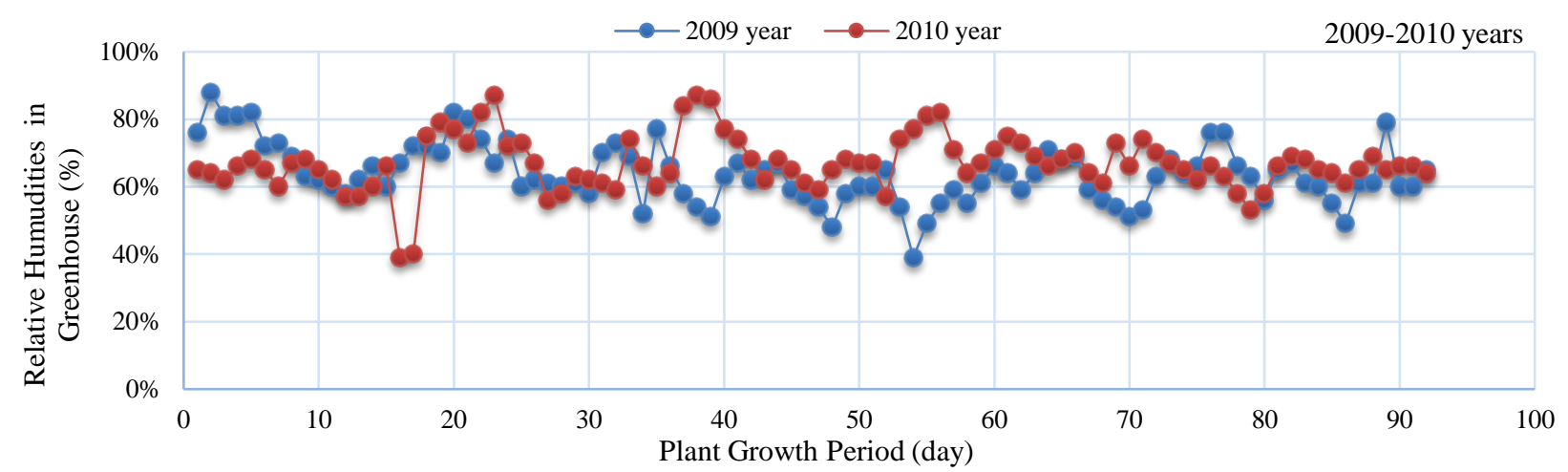

Figure 3 Relative humidities in greenhouse during the plant growth period in 2009-2010 years

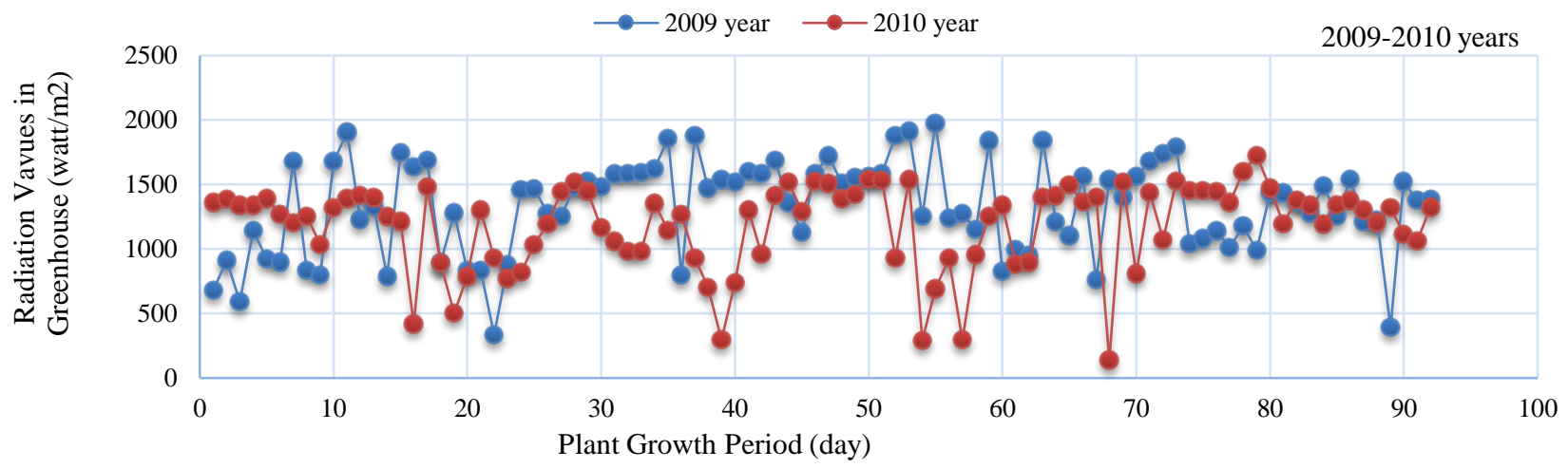

Figure 4 Radiation values in greenhouse during the plant growth period in 2009-2010 years

Table 1 Some specific properties of the experimental soil

\begin{tabular}{l|cccccccc}
\hline $\begin{array}{c}\text { Soil Depth } \\
(\mathrm{cm})\end{array}$ & $\begin{array}{c}\text { Soil } \\
\text { Type }\end{array}$ & $\begin{array}{c}\text { Unit Weight } \\
\left(\mathrm{gr} \mathrm{cm}^{-3}\right)\end{array}$ & $\begin{array}{c}\text { Field } \\
\text { Capacity }(\%)\end{array}$ & $\begin{array}{c}\text { Wilting } \\
\text { Point }(\%)\end{array}$ & $\mathrm{pH}$ & $\begin{array}{c}\text { Total Salt } \\
(\%)\end{array}$ & $\begin{array}{c}\mathrm{CaCO}_{3} \\
(\%)\end{array}$ & $\begin{array}{c}\text { Organic } \\
\text { Matter }(\%)\end{array}$ \\
\hline $0-30$ & SL & 1.34 & 29.73 & 21.74 & 7.99 & 0.037 & 16.5 & 2.92 \\
$30-60$ & SL & 1.37 & 27.26 & 19.37 & 8.04 & 0.031 & 29.5 & 1.39 \\
$60-90$ & SL & 1.58 & 33.92 & 23.72 & 7.86 & 0.034 & 31.5 & 1.08 \\
$90-120$ & SL & 1.50 & 36.30 & 27.73 & 8.05 & 0.032 & 33.0 & 0.94 \\
\hline
\end{tabular}

SL: Sandy Loam

The soil of study place was sandy clay and $\mathrm{pH}$ value of soil ranged between 7.86 and 8.05 . The specific features of the soil are given in Table 1.

Demre F1 variety was used in the study. Demre F1 is a mid-early type and its fruits are around $15-22 \mathrm{~cm}$. The fruit flesh of Demre F1 is thick and the fruits are bright. The plant of Demre F1 has many branches and its development is very good. In the first harvest of the Demre F1 variety, the fruits are sweet and in the later harvests fruits are bitter. This variety has a wide adaptability and high efficiency. In addition, this variety is tolerant to diseases and insects. In the experimental area, an irrigation well was utilized as the source and the water was of the class $C_{1} S_{1}$ after the analysis done. NPK 15-15-15 fertilizer was sprinkled on the soil by hand before planting the seedlings as bottom fertilizer. The application depth of the fertilizer ranged from 15 to $20 \mathrm{~cm}$ depending on the soil structure and the root depth of the plant grown. NPK 15-15-15 fertilizer was utilized to trial plots while the peppers were being planted, and $750 \mathrm{~kg}$ of NPK 15-15-15 fertilizer per hectares were utilized. The urea form of the nitrogen was applied to the plots together with the irrigation water. The first manure was applied as $250 \mathrm{~kg} / \mathrm{ha}(\% 46 \mathrm{~N})$ in the flowering stage and the second fertilizer was utilized as $250 \mathrm{~kg} / \mathrm{ha}$ in yield formation stage together with the irrigation water. Furthermore, in 2009 and 2010 years, $250 \mathrm{~kg}$ of magnesium nitrate manure per hectares $(11-0-0+16 \mathrm{MgO}$ - Nitrogen $11 \%$ and $\mathrm{MgO}$ $16 \%$ ) were used in the flowering and early yield formation stages to support the generative development. In the greenhouse was chlorphtifos-ethyl sprayed $10 \mathrm{~L} \mathrm{ha}^{-1}$ to the peppers for insects.

The plots of the randomized experimental design were formed with three replications and 14 trial treatments were randomly scattered. The size of the experimental plots was $4 \mathrm{~m}^{2}(2.0 \mathrm{~m} \times 2.0 \mathrm{~m})$. The distances between the plots were $0.80 \mathrm{~m}$ and blocks were placed with $1.5 \mathrm{~m}$ distances. The pepper seeds (Demre F1) were sown in viyols on 10 April 2009 and on 06 April 2010 in the experimental years. The pepper seedlings were transplanted to the plots on 10 May 2009 and on 07 May 2010. The seedlings were grown with $20 \mathrm{~cm}$ intervals on the same row and with $10 \mathrm{~cm}$ intervals between the plant lines. Into each plot, 126 plants were planted.

Some quality parameters of pepper are yield, fruit weight, diameter, length and dry matter ratio. The fruit weight was determined by weighting 36 plants in the harvest part and fruit diameter and height were calculated by gauging the weighted fruit with a ruler and by taking the 
average of these values. The dry matter ratio was obtained after they were dried at $65^{\circ} \mathrm{C}$ in a drying oven for $48 \mathrm{~h}$ and fruit dry matter ratio was calculated. The detail of the experimental plot is shown in Figure 5.

In different growth periods of pepper (Vegetative (V), flowering $(\mathrm{F})$, yield formation (Y) and ripening $(\mathrm{R})$ ) fourteen deficit irrigation treatments were formed depending on full or deficit irrigation treatments. 75-50$25 \%$ of the deficit irrigations were applied in different growth stages of the plant, while $100 \%$ of irrigation water was used in full irrigation treatment. In line with this planning, irrigation treatments were planned like this: $\mathrm{V}_{100} \mathrm{~F}_{100} \mathrm{Y}_{100} \mathrm{R}_{100}, \mathrm{~V}_{75} \mathrm{FYR}, \mathrm{V}_{50} \mathrm{FYR}, \mathrm{V}_{25} \mathrm{FYR}, \mathrm{VF}_{75} \mathrm{YR}$, $\mathrm{VF}_{50} \mathrm{YR}, \mathrm{VF}_{25} \mathrm{YR}, \mathrm{VFY}_{75} \mathrm{R}, \mathrm{VFY}_{50} \mathrm{R}, \mathrm{VFY}_{25} \mathrm{R}, \mathrm{VFYR}_{75}$,

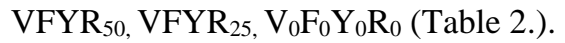

The drip irrigation equipment in greenhouse used in the study was given in Figure 6.

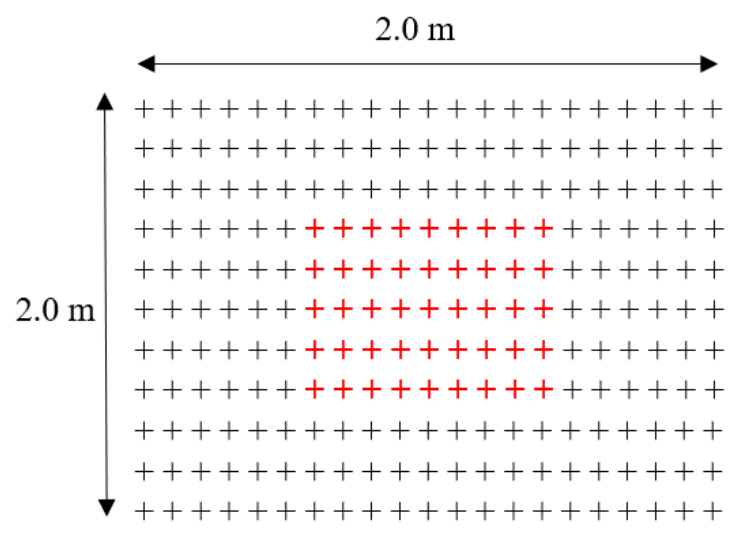

Figure 5 The detail of a plot

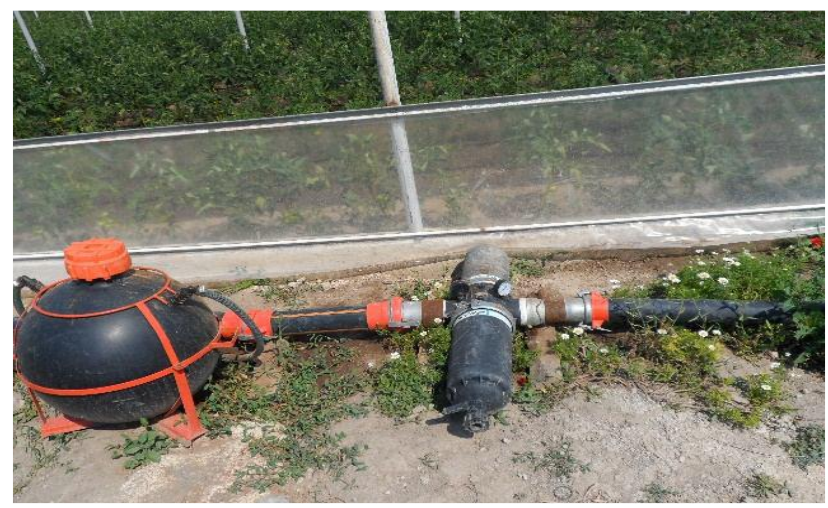

(a)

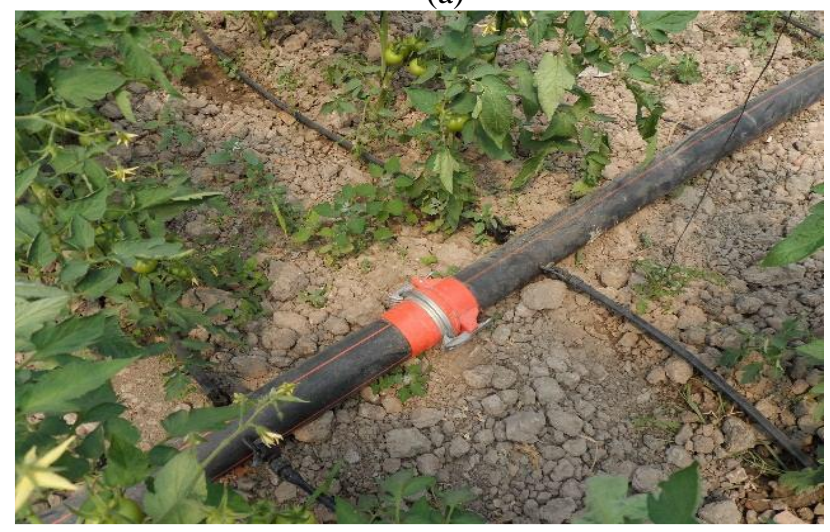

(b)

Figure 6 (a) Drip irrigation system, (b) Main and lateral pipes
In the trial, the plants were irrigated by drip irrigation method and water was used an irrigation well. Some features of the irrigation water were given in Table 3 . The irrigation water has low-sodium risk and medium EC and its class in $\mathrm{C}_{2} \mathrm{~S}_{1}$ class. $\mathrm{C} 2 \mathrm{~S} 1$ irrigation water quality class has low sodium and medium electrical conductivity (salinity). Water in the C2S1 quality class can be used for be irrigated medium and highly resistant plants to salinity. In addition, C1S1 quality class water can be used in all plants and soil without creating harmful alkalinity. A study has been conducted on irrigating pepper by using C2S1 quality class water (Ashraf and Ewees, 2008).

In four growth stages the soil moisture contains of the soil was followed before and after irrigation with a gravimetric method in every $30 \mathrm{~cm}$ up to $120 \mathrm{~cm}$ depth. The water balance equation was used to calculate evapotranspiration (ET), (Eq. 1) (Howell et al., 1995).

$$
\mathrm{ET}=\mathrm{I}+\mathrm{P}-\mathrm{R}_{\mathrm{f}}-\mathrm{D}_{\mathrm{p}} \pm \Delta \mathrm{S}
$$

Where, ET represents the evapotranspiration, I shows the irrigation water amount during the period $(\mathrm{mm}), \mathrm{P}$ is the total precipitation, $R_{f}$ is the amount of the surface flow $(\mathrm{mm}), \mathrm{D}_{\mathrm{p}}$ indicates the deep drainage $(\mathrm{mm})$ and $\Delta \mathrm{S}$ is the soil water content at the beginning and end of the period $(\mathrm{mm} / 120 \mathrm{~cm})$. Before planting seedlings, water was given to the crop by the drip irrigation method. Total precipitation $(\mathrm{P})$ and surface flow $\left(\mathrm{R}_{\mathrm{f}}\right)$ were omitted due to the plant production in the greenhouse. The soil water in the deeper than $120 \mathrm{~cm}$ was taken as the deep drainage $\left(D_{p}\right)$ and the deep drainage (Dp) was neglected. The intervals of lateral were equal to the plant row intervals in the trial. Therefore the percentage of wetted area was calculated by the equation as follows (Eq. 2) (Güngör and Yıldırım, 1989).

$$
\mathrm{P}=\frac{\mathrm{Sd}}{\mathrm{Sl}} 100
$$

Where $\mathrm{P}$ is the percentage of wetted area, $\mathrm{Sd}$ and $\mathrm{Sl}$ are the interval of dripper and the intervals of lateral, respectively. The amount of irrigation water to be applied in each irrigation (Eq.3) was found by the equation given below.

$$
\mathrm{dn}=\frac{(\mathrm{FC}-\mathrm{WP}) \mathrm{Ry}}{100} \mathrm{yt} \mathrm{D} \frac{\mathrm{P}}{100}
$$

Where dn is the amount of irrigation water to be applied in each irrigation, FC and WP are the field capacity and wilting point, respectively. $\mathrm{yt}$ is the soil bulk density, D is wetted soil depth, $\mathrm{P}$ is the percentage of wetted area. In this study, the relationships between yield and ET was described by Steward Model (Eq.4) (Stewart et al., 1975; Doorenbos and Kassam, 1979). The equation can be given as;

$$
\left(1-\frac{Y a}{Y m}\right)=k y\left(1-\frac{E T a}{E T m}\right)
$$

Where $Y_{m}(t / h a)$ and $Y_{a}(t / h a)$ are maximum and actual yield, respectively, $\mathrm{ET}_{\mathrm{m}}(\mathrm{mm})$ and $\mathrm{ET}_{\mathrm{a}}(\mathrm{mm})$ are maximum and actual evapotranspiration, respectively. The yield response factor is shown as $\mathrm{k}_{\mathrm{y}}$. WUE values were 
determined to assess irrigation efficiency in treatments. WUE and IWUE terms refer to contribution of irrigation water to effective use of plant production stages (Bos, 1980). WUE was calculated by dividing the fruit yield by seasonal evapotranspiration (ET). (ET). IWUE was predicted as (Eq.5) (Zhang et al., 1999):

$$
\mathrm{IWUE}=\frac{(\mathrm{Y} 1-\mathrm{YNI})}{\mathrm{I}}
$$

Where $Y_{1}$ is fruit yield of irrigated treatments $\left(t\right.$ ha $\left.{ }^{-1}\right)$ and $\mathrm{Y}_{\mathrm{NI}}$ is the fruit yield of non-irrigated treatment $\left(\mathrm{t} \mathrm{ha}^{-1}\right)$ and $I$ is the amount of irrigation water $(\mathrm{mm})$. The water content of the soil up to $120 \mathrm{~cm}$ depth was calculated before the seedlings were planted into the soil. Before starting irrigations, moisture level of the soil was completed to the level of field capacity in all treatments. Irrigation was begun on May 10 in 2009 and May 07 in 2010 and it was repeated every 7 days. Because of the moisture level in the soil was fulfilled to the field capacity before planting the seedlings, there was no need to apply sap after planting. The irrigation water amounts for the four growth periods of pepper were given in Table 4. Crop evapotranspiration for growth periods of pepper were given in Table 5.

Yield and quality parameters were evaluated. Variance analysis of yield and quality parameters were evaluated according to LSD multiple comparison test $(\mathrm{P}<0.05)$. Variance analysis was done with the values of yield productivity and quality parameters by using MSTAT-C and MINITAB software (Steel and Torrie, 1980).

Table 2 The experimental treatments

\begin{tabular}{|c|c|c|c|c|}
\hline \multirow{2}{*}{ Treatments } & \multicolumn{4}{|c|}{ Growth Stages } \\
\hline & Establishment & Vegetative & Yield Formation & Ripening \\
\hline $\mathrm{E}_{100} \mathrm{~V}_{100} \mathrm{Y}_{100} \mathrm{R}_{100}$ & + & + & + & + \\
\hline $\mathrm{E}_{75} \mathrm{VYR}$ & $\% 25$ deficit irrigation & + & + & + \\
\hline $\mathrm{E}_{50} \mathrm{VYR}$ & $\% 50$ deficit irrigation & + & + & + \\
\hline $\mathrm{E}_{25} \mathrm{VYR}$ & $\% 75$ deficit irrigation & + & + & + \\
\hline $\mathrm{EV}_{75} \mathrm{YR}$ & + & $\% 25$ deficit irrigation & + & + \\
\hline $\mathrm{EV}_{50} \mathrm{YR}$ & + & $\% 50$ deficit irrigation & + & + \\
\hline $\mathrm{EV}_{25} \mathrm{YR}$ & + & $\% 75$ deficit irrigation & + & + \\
\hline $\mathrm{EVY}_{75} \mathrm{R}$ & + & + & $\% 25$ deficit irrigation & + \\
\hline $\mathrm{EVY}_{50} \mathrm{R}$ & + & + & $\% 50$ deficit irrigation & + \\
\hline $\mathrm{EVY}_{25} \mathrm{R}$ & + & + & $\% 75$ deficit irrigation & + \\
\hline $\mathrm{EVYR}_{75}$ & + & + & + & $\% 25$ deficit irrigation \\
\hline $\mathrm{EVYR}_{50}$ & + & + & + & $\% 50$ deficit irrigation \\
\hline $\mathrm{EVYR}_{25}$ & + & + & + & $\% 75$ deficit irrigation \\
\hline $\mathrm{E}_{0} \mathrm{~V}_{0} \mathrm{Y}_{0} \mathrm{R}_{0}$ & - & - & - & - \\
\hline
\end{tabular}

+: Water application in the specified period, -: Without irrigation

Table 3 Specific properties of irrigation water used in the trial

\begin{tabular}{|c|c|c|c|c|c|c|c|c|}
\hline \multirow{2}{*}{$\begin{array}{l}\text { Water } \\
\text { Source }\end{array}$} & \multirow{2}{*}{$\mathrm{EC}_{25} \times\left(10^{6}\right)$} & $\mathrm{Na}^{+}$ & $\mathrm{K}^{+}$ & $\mathrm{Ca}^{2+}$ & $\mathrm{Mg}^{2+}$ & \multirow{2}{*}{$\mathrm{pH}$} & \multirow{2}{*}{ Class } & \multirow{2}{*}{ SAR } \\
\hline & & & & & & & & \\
\hline Deep well & 715 & 2.3 & 2.56 & 9.25 & 5.7 & 7.12 & $\mathrm{C}_{2} \mathrm{~S}_{1}$ & 0.85 \\
\hline
\end{tabular}

Table 4 The irrigation water applied for four growth stages

\begin{tabular}{|c|c|c|c|c|c|c|c|c|c|c|}
\hline \multicolumn{11}{|c|}{ Irrigation Water $(\mathrm{mm})$} \\
\hline \multirow[t]{2}{*}{ Treatments } & \multicolumn{2}{|c|}{ Vegetative } & \multicolumn{2}{|c|}{ Flowering } & \multicolumn{2}{|c|}{$\begin{array}{c}\text { Yield } \\
\text { Formation }\end{array}$} & \multicolumn{2}{|c|}{ Ripening } & \multicolumn{2}{|c|}{ Total } \\
\hline & 2009 & 2010 & 2009 & 2010 & 2009 & 2010 & 2009 & 2010 & 2009 & 2010 \\
\hline $\mathrm{V}_{100 \mathrm{~F}} 100 \mathrm{Y}_{100 \mathrm{R}} 100$ & 180 & 178 & 220 & 220 & 240 & 248 & 104 & 104 & 744.0 & 750.0 \\
\hline V75FYR & 135 & 134 & 220 & 220 & 240 & 248 & 104 & 104 & 699.0 & 706.0 \\
\hline V50FYR & 90 & 89 & 220 & 220 & 240 & 248 & 104 & 104 & 654.0 & 661.0 \\
\hline $\mathrm{V}_{25 \mathrm{FYR}}$ & 45 & 44 & 220 & 220 & 240 & 248 & 104 & 104 & 609.0 & 616.0 \\
\hline VF75YR & 180 & 178 & 165 & 165 & 240 & 248 & 104 & 104 & 689.0 & 695.0 \\
\hline VF50YR & 180 & 178 & 110 & 110 & 240 & 248 & 104 & 104 & 634.0 & 640.0 \\
\hline $\mathrm{VF}_{25} \mathrm{YR}$ & 180 & 178 & 55 & 55 & 240 & 248 & 104 & 104 & 579.0 & 585.0 \\
\hline VFY75R & 180 & 178 & 220 & 220 & 180 & 186 & 104 & 104 & 684.0 & 688.0 \\
\hline VFY $50 R$ & 180 & 178 & 220 & 220 & 120 & 124 & 104 & 104 & 624.0 & 626.0 \\
\hline VFY25R & 180 & 178 & 220 & 220 & 60 & 62 & 104 & 104 & 564.0 & 564.0 \\
\hline VFYR75 & 180 & 178 & 220 & 220 & 240 & 248 & 78 & 78 & 718.0 & 724.0 \\
\hline VFYR50 & 180 & 178 & 220 & 220 & 240 & 248 & 52 & 52 & 692.0 & 698.0 \\
\hline VFYR25 & 180 & 178 & 220 & 220 & 240 & 248 & 26 & 26 & 666.0 & 672.0 \\
\hline $\mathrm{V}_{0} \mathrm{~F}_{0} \mathrm{Y}_{0} \mathrm{R}_{0}$ & 0 & 0 & 0 & 0 & 0 & 0 & 0 & 0 & 0.0 & 0.0 \\
\hline
\end{tabular}


Table 5 Crop evapotranspiration for different growth stages

\begin{tabular}{|c|c|c|c|c|c|c|c|c|c|c|}
\hline \multicolumn{11}{|c|}{ Crop Evapotranspiration (mm) } \\
\hline \multirow{2}{*}{ Treatments } & \multicolumn{2}{|c|}{ Vegetative } & \multicolumn{2}{|c|}{ Flowering } & \multicolumn{2}{|c|}{ Yield Formation } & \multicolumn{2}{|c|}{ Ripening } & \multicolumn{2}{|c|}{ Total } \\
\hline & 2009 & 2010 & 2009 & 2010 & 2009 & 2010 & 2009 & 2010 & 2009 & 2010 \\
\hline V100F100Y100R100 & 160 & 164 & 220 & 220 & 240 & 246 & 140 & 140 & 760 & 770 \\
\hline V75FYR & 155 & 162 & 210 & 215 & 232 & 220 & 128 & 127 & 725 & 724 \\
\hline V50FYR & 136 & 142 & 214 & 215 & 214 & 216 & 116 & 107 & 680 & 680 \\
\hline V25FYR & 126 & 130 & 212 & 212 & 188 & 190 & 116 & 114 & 642 & 646 \\
\hline VF75YR & 147 & 145 & 218 & 216 & 226 & 238 & 133 & 135 & 724 & 734 \\
\hline VF50YR & 148 & 148 & 220 & 218 & 208 & 203 & 104 & 112 & 680 & 681 \\
\hline VF25YR & 136 & 135 & 190 & 195 & 196 & 184 & 102 & 114 & 624 & 628 \\
\hline VFY75R & 149 & 147 & 216 & 212 & 230 & 236 & 125 & 127 & 720 & 722 \\
\hline VFY50R & 129 & 132 & 215 & 226 & 200 & 208 & 112 & 92 & 656 & 658 \\
\hline VFY25R & 120 & 125 & 186 & 180 & 205 & 208 & 93 & 95 & 604 & 608 \\
\hline VFYR75 & 155 & 157 & 220 & 218 & 236 & 243 & 139 & 133 & 750 & 751 \\
\hline VFYR50 & 152 & 158 & 218 & 216 & 236 & 232 & 130 & 136 & 736 & 742 \\
\hline VFYR25 & 154 & 160 & 220 & 220 & 235 & 242 & 93 & 89 & 702 & 711 \\
\hline VOFOYOR0 & 70 & 70 & 90 & 90 & 100 & 100 & 60 & 70 & 320 & 330 \\
\hline
\end{tabular}

Table 6 Relationship between yield and yield response factor (ky) with the decrease in water use, for pepper in 2009 and 2010 years.

\begin{tabular}{|c|c|c|c|c|c|c|c|c|c|}
\hline Treatment & $\mathrm{Y}$ & AW & $\mathrm{E}$ & $\mathrm{E} / \mathrm{E}$ & $\mathrm{Y} / \mathrm{Y}$ & $1-\mathrm{E} / \mathrm{E}$ & $1-\mathrm{Y} / \mathrm{Y}$ & ky & ky \\
\hline V100F100Y100R100 & 26.2 & 744.0 & 760.0 & 1.000 & 1.000 & 0.000 & 0.000 & 0.000 & 0.000 \\
\hline V75FYR & 25.5 & 699.0 & 725.0 & 0.954 & 0.973 & 0.046 & 0.027 & 0.580 & \\
\hline V50FYR & 24.1 & 654.0 & 680.0 & 0.895 & 0.920 & 0.105 & 0.080 & 0.761 & 0.652 \\
\hline V25FYR & 23.7 & 609.0 & 642.0 & 0.845 & 0.905 & 0.155 & 0.095 & 0.615 & \\
\hline VF75YR & 23.3 & 689.0 & 724.0 & 0.953 & 0.889 & 0.047 & 0.111 & 2.337 & \\
\hline VF50YR & 22.9 & 634.0 & 680.0 & 0.895 & 0.874 & 0.105 & 0.126 & 1.197 & 1.469 \\
\hline VF25YR & 22.4 & 579.0 & 634.0 & 0.834 & 0.855 & 0.166 & 0.145 & 0.875 & \\
\hline VFY75R & 21.8 & 684.0 & 720.0 & 0.947 & 0.832 & 0.053 & 0.168 & 3.191 & \\
\hline VFY50R & 21.0 & 624.0 & 656.0 & 0.863 & 0.802 & 0.137 & 0.198 & 1.450 & 1.925 \\
\hline VFY25R & 20.1 & 564.0 & 604.0 & 0.795 & 0.767 & 0.205 & 0.233 & 1.134 & \\
\hline VFYR75 & 26.0 & 718.0 & 740.0 & 0.974 & 0.992 & 0.026 & 0.008 & 0.290 & \\
\hline VFYR50 & 25.8 & 692.0 & 736.0 & 0.968 & 0.985 & 0.032 & 0.015 & 0.483 & 0.375 \\
\hline VFYR25 & 25.5 & 666.0 & 702.0 & 0.924 & 0.973 & 0.076 & 0.027 & 0.350 & \\
\hline \multirow[t]{2}{*}{ VOFOYOR0 } & 0.2 & 0.0 & 320.0 & 0.421 & 0.008 & 0.579 & 0.992 & 1.714 & 1.669 \\
\hline & & & & & & & & & 1.29 \\
\hline Treatment & $\mathrm{Y}$ & AW & $\mathrm{E}$ & $\mathrm{E} / \mathrm{E}$ & $\mathrm{Y} / \mathrm{Y}$ & $1-\mathrm{E} / \mathrm{E}$ & $1-\mathrm{Y} / \mathrm{Y}$ & ky & ky \\
\hline V100F100Y100R100 & 27.8 & 750.0 & 770.0 & 1.000 & 1.000 & 0.000 & 0.000 & 0.000 & 0.000 \\
\hline V75FYR & 25.9 & 706.0 & 724.0 & 0.940 & 0.932 & 0.060 & 0.068 & 1.144 & \\
\hline V50FYR & 25.5 & 661.0 & 680.0 & 0.883 & 0.917 & 0.117 & 0.083 & 0.708 & 0.826 \\
\hline V25FYR & 25.0 & 616.0 & 646.0 & 0.839 & 0.899 & 0.161 & 0.101 & 0.625 & \\
\hline VF75YR & 24.2 & 695.0 & 734.0 & 0.953 & 0.871 & 0.047 & 0.129 & 2.770 & \\
\hline VF50YR & 24.0 & 640.0 & 681.0 & 0.884 & 0.863 & 0.116 & 0.137 & 1.183 & 1.591 \\
\hline VF25YR & 23.6 & 585.0 & 628.0 & 0.816 & 0.849 & 0.184 & 0.151 & 0.819 & \\
\hline VFY75R & 23.5 & 688.0 & 722.0 & 0.938 & 0.845 & 0.062 & 0.155 & 2.481 & \\
\hline VFY50R & 22.9 & 626.0 & 658.0 & 0.855 & 0.824 & 0.145 & 0.176 & 1.212 & 1.550 \\
\hline VFY25R & 22.2 & 564.0 & 608.0 & 0.790 & 0.799 & 0.210 & 0.201 & 0.957 & \\
\hline VFYR75 & 27.5 & 724.0 & 751.0 & 0.975 & 0.989 & 0.025 & 0.011 & 0.437 & \\
\hline VFYR50 & 27.2 & 698.0 & 742.0 & 0.975 & 0.978 & 0.025 & 0.022 & 0.875 & 0.563 \\
\hline VFYR25 & 27.0 & 672.0 & 711.0 & 0.923 & 0.971 & 0.077 & 0.029 & 0.376 & \\
\hline \multirow[t]{2}{*}{ VOFOYOR0 } & 0.3 & 0.0 & 330.0 & 0.429 & 0.011 & 0.571 & 0.989 & 1.731 & 1.759 \\
\hline & & & & & & & & & 1.24 \\
\hline
\end{tabular}

Y: Yield $\left(\mathrm{t} \mathrm{ha}^{-1}\right)$, AW: Applied Water (mm), E: ETa (mm), E/E: ETa/ETm, Y/Y: Ya/Ym,

\section{Results}

In 2009 and 2010 years, the highest irrigation water was found in $\mathrm{V}_{100} \mathrm{~F}_{100} \mathrm{Y}_{100} \mathrm{R}_{100}$ treatment as $744-750 \mathrm{~mm}$ and minimal irrigation water was found in $\mathrm{V}_{0} \mathrm{~F}_{0} \mathrm{Y}_{0} \mathrm{R}_{0}$ treatment as $0-0 \mathrm{~mm}$ respectively. Crop water use of pepper $\left(\mathrm{ET}_{\mathrm{c}}\right)$ increased with the increment in the water amount. ET was found as $320-760 \mathrm{~mm}$ in 2009 and as $330-770 \mathrm{~mm}$ in 2010 in $\mathrm{V}_{100} \mathrm{~F}_{100} \mathrm{Y}_{100} \mathrm{R}_{100}$ and $\mathrm{V}_{0} \mathrm{~F}_{0} \mathrm{Y}_{0} \mathrm{R}_{0}$ treatments, respectively. The irrigation water and yields are presented in Table 6 .
Crop water production functions ( $\mathrm{k}_{\mathrm{y}}$ and $\mathrm{R}^{2}$ values) obtained for each growth stage (vegetative, flowering, yield formation, ripening) and total growing season in 2009 and 2010 were given in Table 7.

Linear relationships between $\mathrm{ET}_{\mathrm{c}}$ with $\mathrm{Y}_{\mathrm{a}}$, and IW with $Y_{a}$ were observed for 2009 year. The relationship equation is as follows; $\mathrm{Y}_{\mathrm{a}}=0.0572 \mathrm{ET}_{\mathrm{c}}-16.045$ with $\mathrm{R}^{2}=0.9201$ and $\mathrm{Y}_{\mathrm{a}}=0.352 \mathrm{IW}+0.5366$ with $\mathrm{R}^{2}=0.9615$ (Figure $7 . \mathrm{a}$ and 
7.b). Linear relationships between $\mathrm{ET}_{\mathrm{c}}$ with $\left(\mathrm{Y}_{\mathrm{a}}\right)$, and IW with $\mathrm{Y}_{\mathrm{a}}$ were observed for 2010 year. The relationship equation is as follows; $\mathrm{Y}_{\mathrm{a}}=0.0599 \mathrm{ET}_{\mathrm{c}}-16.819$ with $\mathrm{R}^{2}$ $=0.9085$ and $\mathrm{Y}_{\mathrm{a}}=0.0365 \mathrm{IW}+0.8495$ with $\mathrm{R}^{2}=0.9660$ (Figure 7.a and 7.b).

When the results were taken into consideration, yield was substantially affected by irrigation applications (Figure 7.a and 7.b) the maximum values of yield were found as $26.2 \mathrm{tha}$ ${ }^{1}$ and $27.8 \mathrm{t} \mathrm{ha}^{-1}$ in $\mathrm{V}_{100} \mathrm{~F}_{100} \mathrm{Y}_{100} \mathrm{R}_{100}$ treatment for 2009 and 2010 years, respectively (Table 8 and 9 ).

When $\mathrm{V}_{100} \mathrm{~F}_{100} \mathrm{Y}_{100} \mathrm{R}_{100}$ treatment was made comparison with the other irrigation treatments, yield losses were determined as $2.8 \%, 8.7 \%, 10.6 \%, 12.5 \%$, $14.4 \%, 19.1 \%, 20.2 \%, 24.8 \%, 30.4 \%, 0.8 \%, 1.6 \%, 2.8 \%$, and $13000.0 \%$ in 2009 and $7.3 \%, 9.0 \%, 11.2 \%, 14.9 \%$,
$15.8 \%, 17.8 \%, 18.3 \%, 21.4 \%, 25.2 \%, 1.1 \%, 2.2 \%, 3.0 \%$ and $9166.7 \%$ in 2010 . In the study, it was observed that at $\mathrm{P}<0.05$ level has a significant effect on the yield and quality parameters of deficit irrigation.

While a positive straight line relationship was obtained between the water amount and the yield, fruit weight, diameter, length; a negative straight line relationship was obtained between the irrigation amount and dry matter ratio. As for that the relationship, these results were determined: fruit weight $(2009)=0.0108 \mathrm{IW}+3.8022, \mathrm{R}^{2}$ $=0.9078$ and fruit weight $(2010)=0.0118 \mathrm{IW}+3.2647, \mathrm{R}^{2}$ $=0.9044$ (Fig. 8.a.); fruit diameter $(2009)=0.0033 \mathrm{IW}+$ $0.3341, \mathrm{R}^{2}=0.9231$ and fruit diameter $(2010)=0.0031+$ $0.3293, R^{2}=0.9056$ (Fig. 8.b).

Table 7 Crop water production functions obtained for each growth period and total growing season in 2009 and 2010 years

\begin{tabular}{l|ll}
\hline Year & Period & Production Functions \\
\hline & $\mathrm{E}$ & $\mathrm{ky}=0.652, \mathrm{R}^{2}=0.9330$ \\
& $\mathrm{~V}$ & $\mathrm{ky}=1.469, \mathrm{R}^{2}=0.9999$ \\
& $\mathrm{Y}$ & $\mathrm{ky}=1.925, \mathrm{R}^{2}=0.9913$ \\
& $\mathrm{R}$ & $\mathrm{ky}=0.375, \mathrm{R}^{2}=0.9854$ \\
& Seasonal & $\mathrm{ky}=1.290, \mathrm{R}^{2}=0.9201$ \\
\hline & $\mathrm{E}$ & $\mathrm{ky}=0.826, \mathrm{R}^{2}=0.9811$ \\
& $\mathrm{~V}$ & $\mathrm{ky}=1.591, \mathrm{R}^{2}=0.9643$ \\
& $\mathrm{Y}$ & $\mathrm{ky}=1.550, \mathrm{R}^{2}=0.9868$ \\
& $\mathrm{R}$ & $\mathrm{ky}=0.563, \mathrm{R}^{2}=0.8319$ \\
& Seasonal & $\mathrm{ky}=1.240, \mathrm{R}^{2}=0.9085$ \\
\hline
\end{tabular}

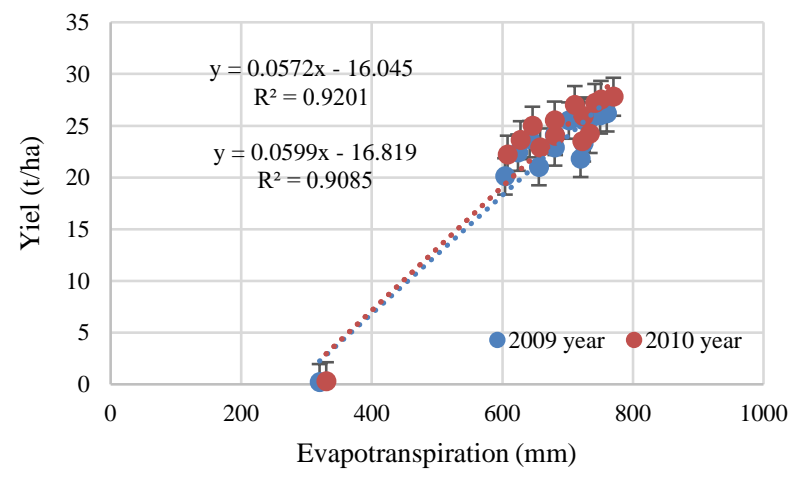

(a)

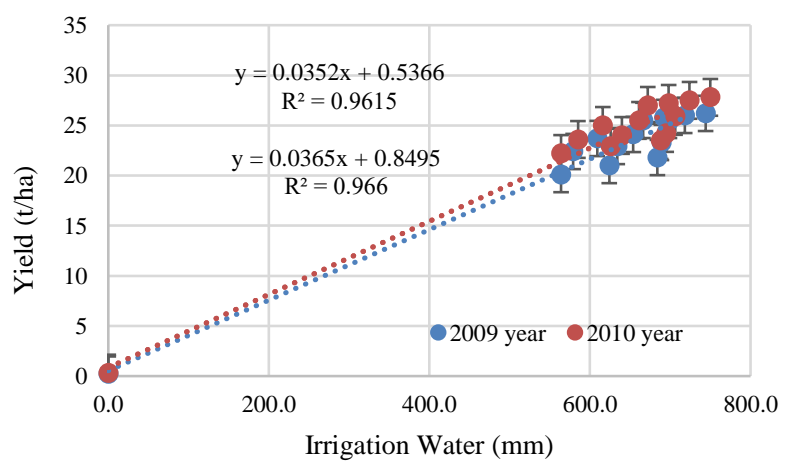

(b)

Figure $7 \mathrm{a}$ The relationship between crop water consumption and yield. $7 \mathrm{~b}$ The relationship between irrigation water and yield

Table 8 Effects of irrigation treatments on yield and quality parameters of pepper in 2009 year.

\begin{tabular}{|c|c|c|c|c|c|}
\hline Irrigation Treatments & Yield $\left(\mathrm{t} \mathrm{ha}^{-1}\right)$ & Fruit Weight (g) & Fruit Diameter $(\mathrm{cm})$ & Fruit Length $(\mathrm{cm})$ & Dry Matter Ratio (\%) \\
\hline $\mathrm{V}_{100} \mathrm{~F}_{100} \mathrm{Y}_{100} \mathrm{R}_{100}$ & $26.2^{\mathrm{a}}$ & $12.2^{\mathrm{a}}$ & $3.2^{\mathrm{a}}$ & $19.5^{\mathrm{a}}$ & $8.1^{\mathrm{i}}$ \\
\hline $\mathrm{V}_{75} \mathrm{FYR}$ & $25.5^{\mathrm{a}}$ & $11.5^{\mathrm{bcd}}$ & $2.5^{\mathrm{bcd}}$ & $17.5 \mathrm{~d}^{\mathrm{e}}$ & $8.2^{\text {hi }}$ \\
\hline $\mathrm{V}_{50} \mathrm{FYR}$ & $24.1^{\mathrm{b}}$ & $11.3^{\text {cde }}$ & $2.4^{\mathrm{bcd}}$ & $17.2^{\text {ef }}$ & $8.3^{\text {hi }}$ \\
\hline $\mathrm{V}_{25} \mathrm{FYR}$ & $23.7^{\mathrm{bc}}$ & $11.0^{\mathrm{def}}$ & $2.3^{\mathrm{cd}}$ & $16.8^{\text {fg }}$ & $8.6 \mathrm{~g}^{\mathrm{hi}}$ \\
\hline $\mathrm{VF}_{75} \mathrm{YR}$ & $23.3^{\mathrm{bcd}}$ & $10.8^{\mathrm{ef}}$ & $2.5^{\mathrm{bcd}}$ & $16.5^{\mathrm{gh}}$ & $8.7 \mathrm{f}^{\text {gh }}$ \\
\hline $\mathrm{VF}_{50} \mathrm{YR}$ & $22.9^{\text {cde }}$ & $10.5^{\text {fg }}$ & $2.4^{\text {bcd }}$ & $16.1^{\mathrm{hi}}$ & $9.0^{\text {efg }}$ \\
\hline $\mathrm{VF}_{25} \mathrm{YR}$ & $22.4^{\text {de }}$ & $10.1^{\mathrm{gh}}$ & $2.3^{\mathrm{cd}}$ & $15.8^{\mathrm{ij}}$ & $9.7^{b c}$ \\
\hline $\mathrm{VFY}_{75} \mathrm{R}$ & $21.8^{\mathrm{ef}}$ & $10.0^{\text {gh }}$ & $2.3^{\mathrm{cd}}$ & $15.5^{\mathrm{j}}$ & $9.1^{\text {defg }}$ \\
\hline $\mathrm{VFY}_{50} \mathrm{R}$ & $21.0^{\mathrm{fg}}$ & $9.6^{\mathrm{hi}}$ & $2.2^{\mathrm{d}}$ & $14.9^{\mathrm{k}}$ & $9.2^{\text {cdef }}$ \\
\hline $\mathrm{VFY}_{25} \mathrm{R}$ & $20.1^{\mathrm{g}}$ & $9.0^{\mathrm{i}}$ & $2.1^{\mathrm{d}}$ & $14.2^{1}$ & $9.8^{\mathrm{b}}$ \\
\hline $\mathrm{VFYR}_{75}$ & $26.0^{\mathrm{a}}$ & $12.0^{\mathrm{ab}}$ & $2.8^{\mathrm{ab}}$ & $18.5^{\mathrm{b}}$ & $9.3^{\text {bcde }}$ \\
\hline VFYR $_{50}$ & $25.8^{\mathrm{a}}$ & $11.9^{\mathrm{abc}}$ & $2.7^{\mathrm{bc}}$ & $18.2^{\mathrm{bc}}$ & $9.6^{\mathrm{bcd}}$ \\
\hline VFYR $_{25}$ & $25.5^{\mathrm{a}}$ & $11.7^{\mathrm{abc}}$ & $2.7^{\mathrm{bc}}$ & $17.9^{\mathrm{cd}}$ & $9.7^{\mathrm{bc}}$ \\
\hline $\mathrm{V}_{0} \mathrm{~F}_{0} \mathrm{Y}_{0} \mathrm{R}_{0}$ & $0.2^{\mathrm{h}}$ & $4.0^{\mathrm{j}}$ & $0.4^{\mathrm{e}}$ & $6.5^{\mathrm{m}}$ & $15.1^{\mathrm{a}}$ \\
\hline Treatments & 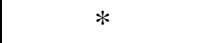 & * & $*$ & * & $*$ \\
\hline Blocks & ns & ns & ns & ns & ns \\
\hline
\end{tabular}

* means correlation is significant at the 0.005 level. ns shows non-significant correlation. 
Table 9 Effects of irrigation treatments on yield and quality parameters of pepper in 2010 year.

\begin{tabular}{|c|c|c|c|c|c|}
\hline Irrigation Treatment & Yield $\left(\mathrm{t} \mathrm{ha}^{-1}\right)$ & Fruit Weight (kg) & Fruit Diameter $(\mathrm{cm})$ & Fruit Length $(\mathrm{cm})$ & Dry Matter Ratio (\%) \\
\hline $\mathrm{V}_{100} \mathrm{~F}_{100} \mathrm{Y}_{100} \mathrm{R}_{100}$ & $27.8^{a}$ & $12.4^{\mathrm{a}}$ & $3.1^{\mathrm{a}}$ & $20.0^{\mathrm{a}}$ & $7.7^{\mathrm{g}}$ \\
\hline $\mathrm{V}_{75} \mathrm{FYR}$ & $25.9^{\mathrm{bcd}}$ & $11.7^{\mathrm{bcd}}$ & $2.5^{\mathrm{bc}}$ & $18.0^{\text {bcd }}$ & $8.1^{\mathrm{fg}}$ \\
\hline $\mathrm{V}_{50} \mathrm{FYR}$ & $25.5^{\mathrm{cde}}$ & $11.5^{\mathrm{cde}}$ & $2.4^{\text {bcd }}$ & $17.7^{\text {bcde }}$ & $8.3^{\text {ef }}$ \\
\hline $\mathrm{V}_{25} \mathrm{FYR}$ & $25.0^{\mathrm{def}}$ & $11.2^{\mathrm{def}}$ & $2.3^{\mathrm{bcd}}$ & $17.5^{\text {cde }}$ & $8.7^{\mathrm{de}}$ \\
\hline $\mathrm{VF}_{75} \mathrm{YR}$ & $24.2^{\text {defg }}$ & $11.0^{\mathrm{ef}}$ & $2.3^{\mathrm{bcd}}$ & $17.0^{\mathrm{def}}$ & $8.5^{\text {ef }}$ \\
\hline $\mathrm{VF}_{50} \mathrm{YR}$ & $24.0^{\text {efg }}$ & $10.7^{\text {fg }}$ & $2.2^{\mathrm{bcd}}$ & $16.7^{\text {def }}$ & $8.6^{\mathrm{e}}$ \\
\hline $\mathrm{VF}_{25} \mathrm{YR}$ & $23.6^{\text {fgh }}$ & $10.3^{\mathrm{gh}}$ & $2.1^{\mathrm{cd}}$ & $16.4^{\mathrm{efg}}$ & $9.4^{\mathrm{bc}}$ \\
\hline $\mathrm{VFY}_{75} \mathrm{R}$ & $23.5^{\text {fgh }}$ & $10.1^{\mathrm{h}}$ & $2.1^{\mathrm{cd}}$ & $15.9^{\text {fgh }}$ & $8.4^{\mathrm{ef}}$ \\
\hline $\mathrm{VFY}_{50} \mathrm{R}$ & $22.9^{\text {gh }}$ & $9.5^{\mathrm{i}}$ & $2.1^{\mathrm{cd}}$ & $15.3^{\mathrm{gh}}$ & $9.1^{\mathrm{cd}}$ \\
\hline $\mathrm{VFY}_{25} \mathrm{R}$ & $22.2^{\mathrm{h}}$ & $8.8^{\mathrm{j}}$ & $2.0^{\mathrm{a}}$ & $14.6^{\mathrm{h}}$ & $9.7^{\mathrm{b}}$ \\
\hline VFYR $_{75}$ & $27.5^{\mathrm{ab}}$ & $12.3^{\mathrm{a}}$ & $2.6^{\mathrm{b}}$ & $19.0^{\mathrm{ab}}$ & $9.5^{\mathrm{bc}}$ \\
\hline $\mathrm{VFYR}_{50}$ & $27.2^{\mathrm{abc}}$ & $12.1^{\mathrm{ab}}$ & $2.6^{\mathrm{b}}$ & $18.8^{\mathrm{abc}}$ & $9.5^{\mathrm{bc}}$ \\
\hline $\mathrm{VFYR}_{25}$ & $27.0^{\mathrm{abc}}$ & $12.0^{\mathrm{abc}}$ & $2.5 b^{c}$ & $18.5^{\mathrm{abc}}$ & $9.6^{\mathrm{b}}$ \\
\hline $\mathrm{V}_{0} \mathrm{~F}_{0} \mathrm{Y}_{0} \mathrm{R}_{0}$ & $0.3^{\mathrm{i}}$ & $3.5^{\mathrm{k}}$ & $0.4^{\mathrm{e}}$ & $6.0^{\mathrm{i}}$ & $15.5^{\mathrm{a}}$ \\
\hline Treatments & $*$ & $*$ & $*$ & * & $*$ \\
\hline
\end{tabular}

*means correlation is significant at the 0.005 level. ns shows non-significant correlation

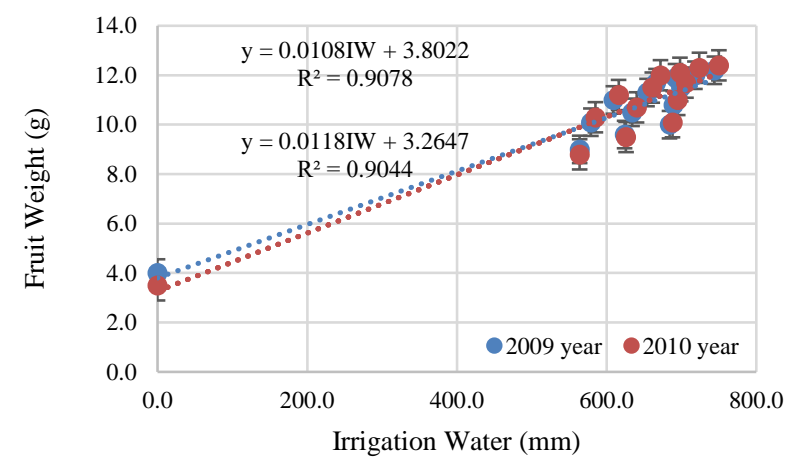

(a)

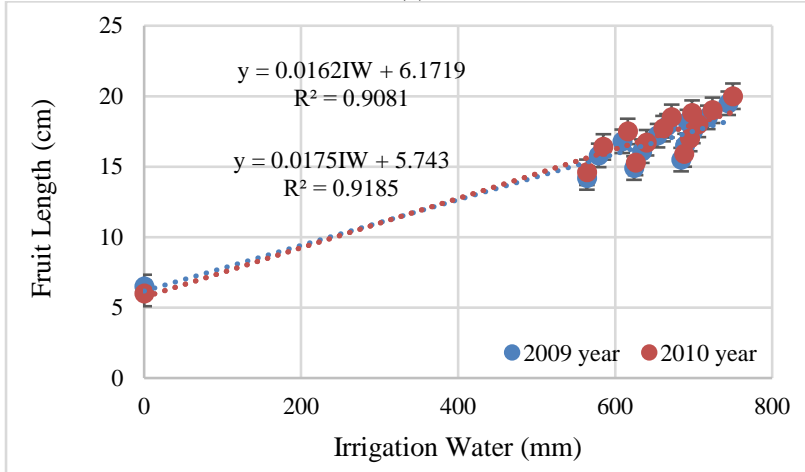

(c)

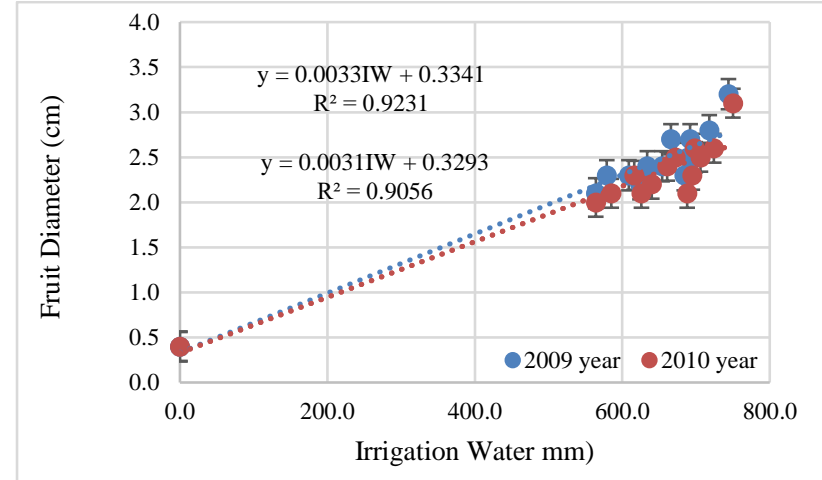

(b)

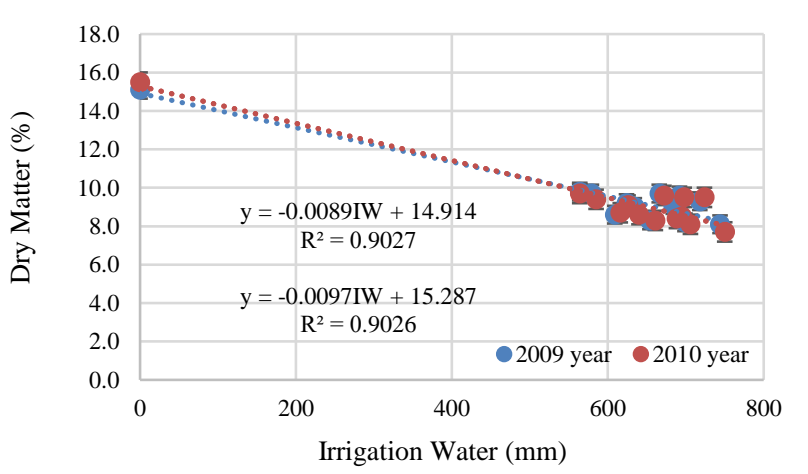

(d)

Figure 8 Relationship between irrigation water and fruit weight, diameter, length and dry matter ratio Fruit length (2009) $=0.0162 \mathrm{IW}+6.1719, \mathrm{R}^{2}=0.9081$ and fruit length $(2010)=0.0175 \mathrm{IW}+5.743, \mathrm{R}^{2}=0.9185$ (Fig. 8.c.); dry matter ratio (2009) $=$ $0.0089 \mathrm{IW}+14.914, \mathrm{R}^{2}=0.9027$ and dry matter ratio $(2010)=-0.0097 \mathrm{IW}+15.287, \mathrm{R}^{2}=0.9026$ (Fig. 8.d.).

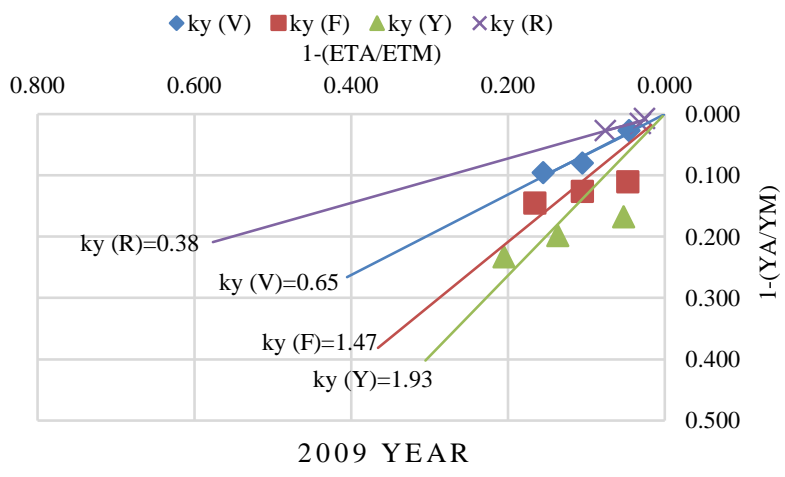

(a)

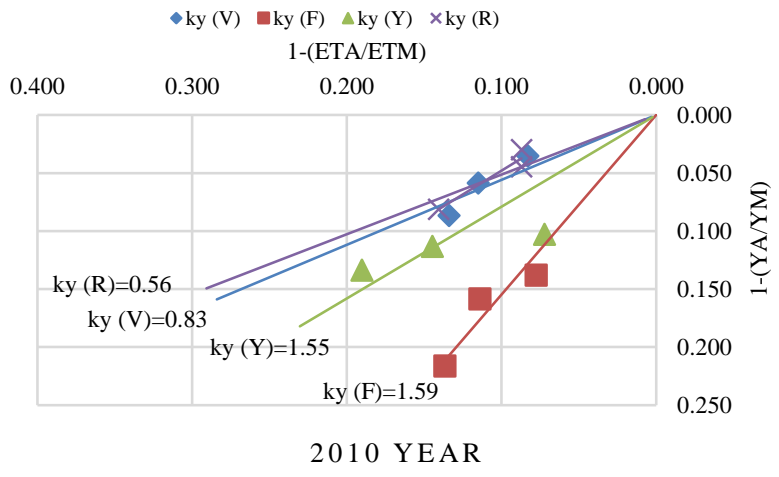

(b)

Figure 9 The relationship between relative yield decrease and relative evapotranspiration deficit for the experimental years 
Crop Yield Response Factor $\left(k_{y}\right)$

The linear relationship between relative crop evapotranspiration and relative yield decrease is given the ky value. It is regarded as the yield response to the relative crop evapotranspiration. In another saying, it represents the declines in the yield as a result of each deficient level in water depletion. Seasonal ky values were determined as 1.29 (2009 year) and 1.24 (2010 year) (Fig.9). Ky value increased with the increase in the water deficit. This result was relatively small with regard to seasonal crop yield response factors in four different crop growth periods of the peppers, while it was consistent with the crop yield response factors in each growth factors given in literature. The difference between these two results may refer to the differences between the empirical, climatic and seedling quality.

Water Use Efficiencies

WUE and IWUE values of the 2009 and 2010 years appeared differently in different treatments (Table 10). The maximum WUE values for 2009 year were found as 0.4 , $0.4,0.4-0.4,0.4,0.4 \mathrm{~kg} \mathrm{~mm}^{-1}$ and were found $0.4,0.4,0.4$ - 0.4, 0.4, $0.4 \mathrm{~kg} \mathrm{~mm}^{-1}$ from V75FYR, V50FYR, V25FYR and VFYR $75, \mathrm{VFYR}_{50}, \mathrm{VFYR}_{25}$ treatments for 2010 year, respectively.

IWUE values for 2009 year were found as $0.4,0.4,0.4$ $-0.4,0.4,0.4 \mathrm{~kg} . \mathrm{mm}^{-1}$ and were found $0.4,0.4,0.4-0.4$, $0.4,0.4 \mathrm{~kg} \mathrm{~mm}^{-1}$ from V75FYR, V50FYR, V25FYR and $\mathrm{VFYR}_{75}, \mathrm{VFYR}_{50}, \mathrm{VFYR}_{25}$ treatments for 2010 year, respectively. When WUE and IWUE values were taken into consideration, the maximum WUE and IWUE values were obtained in vegetative and ripening periods and the lowest value was obtained from flowering and yield formation periods. In other words, the maximum yields were obtained from vegetative and ripening periods and the most water saving was supplied with deficit irrigation only in the vegetative and ripening periods of the pepper.

Table 10 WUE and IWUE values for the pepper at fourteen irrigation treatments.

\begin{tabular}{l|ccc|l|ccc}
\hline \multicolumn{1}{c}{$\begin{array}{c}\text { Irrigation } \\
\text { Treatment }\end{array}$} & $\begin{array}{c}\text { Yield } \\
\left(\mathrm{t} \mathrm{ha}^{-1}\right)\end{array}$ & $\begin{array}{c}\text { WUE } \\
\left(\mathrm{kg} / \mathrm{m}^{3}\right)\end{array}$ & $\begin{array}{c}\text { IWUE } \\
\left(\mathrm{kg} / \mathrm{m}^{3}\right)\end{array}$ & $\begin{array}{c}\text { Irrigation } \\
\text { Treatment }\end{array}$ & $\begin{array}{c}\text { Yield } \\
\left(\mathrm{t} \mathrm{ha}^{-1}\right)\end{array}$ & $\begin{array}{c}\text { WUE } \\
\left(\mathrm{kg} / \mathrm{m}^{3}\right)\end{array}$ & $\begin{array}{c}\text { IWUE } \\
\left(\mathrm{kg} / \mathrm{m}^{3}\right)\end{array}$ \\
\hline V100F100Y100R10 & & & & V100F100Y100R10 & & & \\
0 & 26.2 & 0.03 & 0.04 & 0 & 27.8 & 0.04 & 0.04 \\
V75FYR & 25.5 & 0.04 & 0.04 & V75FYR & 25.9 & 0.04 & 0.04 \\
V50FYR & 24.1 & 0.04 & 0.04 & V50FYR & 25,5 & 0.04 & 0.04 \\
V25FYR & 23.7 & 0.04 & 0.04 & V25FYR & 25.0 & 0.04 & 0.04 \\
VF75YR & 23.3 & 0.03 & 0.03 & VF75YR & 24,2 & 0.03 & 0.03 \\
VF50YR & 22.9 & 0.03 & 0.04 & VF50YR & 24.0 & 0.04 & 0.04 \\
VF25YR & 22.0 & 0.03 & 0.04 & VF25YR & 23.6 & 0.04 & 0.04 \\
VFY75R & 21.8 & 0.03 & 0.03 & VFY75R & 23.5 & 0.03 & 0.03 \\
VFY50R & 21.0 & 0.03 & 0.03 & VFY50R & 22.9 & 0.03 & 0.04 \\
VFY25R & 20.1 & 0.03 & 0.04 & VFY25R & 22.2 & 0.04 & 0.04 \\
VFYR75 & 26.0 & 0.04 & 0.04 & VFYR75 & 27.5 & 0.04 & 0.04 \\
VFYR50 & 25.8 & 0.04 & 0.04 & VFYR50 & 27.2 & 0.04 & 0.04 \\
VFYR25 & 25.5 & 0.04 & 0.04 & VFYR25 & 27.0 & 0.04 & 0.04 \\
V0F0Y0R0 & 0.2 & 0.00 & 0.00 & V0F0Y0R0 & 0.3 & 0.00 & 0.00 \\
\hline
\end{tabular}

\section{Discussion}

In this experiment, irrigation treatments considerably influenced yield, fruit weight, diameter, length and dry matter. In both experimental years, the maximum amounts of water applied to the crop were 744-750 $\mathrm{mm}$ for from $\mathrm{V}_{100} \mathrm{~F}_{100} \mathrm{Y}_{100} \mathrm{R}_{100}$ while the seasonal evapotranspiration (ETa) values were changed between 760-320 mm and 770$330 \mathrm{~mm}$ for $\mathrm{V}_{0} \mathrm{~F}_{0} \mathrm{Y}_{0} \mathrm{R}_{0}$ treatment. Total water requirements was 600 to $900 \mathrm{~mm}$ and up to $1250 \mathrm{~mm}$ for long growing periods and several pickings (Doorenbos and Kassam, 1979). In a study conducted by Goldberg and Shmueli (1971) in Israel, they applied $1340 \mathrm{~mm}$ irrigation water during the plant growing season. Demirtas and Ayas (2009) stated that irrigation water amount applied for 65$724 \mathrm{~mm}$ in different treatments in the province of Bursa of Turkey. In a study conducted in Hungary by Posgay (1972), the water consumption of the pepper was $719 \mathrm{~mm}$ in furrow irrigation and $625 \mathrm{~mm}$ in porous pipe irrigation. Sezen et al. (2006) determined that crop evapotranspiration (ET) values varied from $365 \mathrm{~mm}$ to $528 \mathrm{~mm}$ in the first experimental year and $309 \mathrm{~mm}$ to $511 \mathrm{~mm}$ in the second experimental year. Smittle et al. (1994) also reported that the water applied of pepper changed from $207 \mathrm{~mm}$ to 396 $\mathrm{mm}$. Plant water consumption in this study changed from $425 \mathrm{~mm}$ to $656 \mathrm{~mm}$. Chartzoulakis and Drosos (1999) indicated that the seasonal irrigation water of pepper changed from 132 to $329 \mathrm{~mm}$ in first year and from 147$366 \mathrm{~mm}$ in second year. Gencoglan et al., (2006) specified that the most economical irrigation levels, in terms of both net income from per unit of land and water, were $815 \mathrm{~mm}$ and $752 \mathrm{~mm}$, respectively.

The pepper yield ranged between 26.2-0.2 and 27.8-0.3 t ha-1 for 2009 and 2010 years, respectively. Yield was decreased as the irrigation water amount reduced. As a result, the effect of deficit irrigation was found significant on total yield. This result was compatible with those of (Doorenbos and Kassam, 1979; Chartzoulakis and Drosos, 1999; Demirtas and Ayas, 2009; Gencoglan et al., 2006). As in yield, some quality parameters of pepper (fruit weight, diameter, length and dry matter) showed a similar response to deficit irrigation.

As for fruit weight, there was influence of deficiency irrigation on single fruit weight with respect to quality parameters. As observed in yield, the fruit diameter and weight gave similar response to deficit irrigation. The 
highest quality parameters were obtained from $\mathrm{V}_{100} \mathrm{~F}_{100} \mathrm{Y}_{100} \mathrm{R}_{100}$ treatments every two experiment years. The non-irrigated $\left(\mathrm{V}_{0} \mathrm{~F}_{0} \mathrm{Y}_{0} \mathrm{R}_{0}\right)$ treatment had lower values than all irrigation treatments. The result of study were in conformance with (Chartzoulakis and Drosos, 1999; Braga and Klar, 2003; Sezen et al., 2006; Demirtas and Ayas, 2009; Gul et al., 2011). Since $\mathrm{V}_{100} \mathrm{~F}_{100} \mathrm{Y}_{100} \mathrm{R}_{100}$ treatments had higher fruit weight than the other treatments, the lowest dry matters have been found at $\mathrm{V}_{100} \mathrm{~F}_{100} \mathrm{Y}_{100} \mathrm{R}_{100}$ treatments when the highest dry matter values were observed at $\mathrm{V}_{0} \mathrm{~F}_{0} \mathrm{Y}_{0} \mathrm{R}_{0}$ treatments in both years of the experiment. As a result, we may say that as the amount of irrigation water decrease, the number of dry matter increases. These values are similar to those of previous studies (Chartzoulakis and Drosos, 1999; Gencoglan et al., 2006; Sezen et al., 2006; Demirtas and Ayas, 2009; Gul et al., 2011). The maximum WUE values for 2009 year were found as 0.04, 0.04, 0.04 $-0.04,0.04,0.04 \mathrm{~kg} \mathrm{~mm}^{-1}$ and were found as $0.04,0.04$, $004-0.04,0.04,0.04 \mathrm{~kg} \mathrm{~mm}^{-1}$ from V75FYR, V50FYR, V25FYR and $\mathrm{VFYR}_{75}, \mathrm{VFYR}_{50}, \mathrm{VFYR}_{25}$ treatments for 2010 year, respectively. IWUE values for 2009 year were found as $0.04,0.04,0.04-0.04,0.04,0.04 \mathrm{~kg} . \mathrm{mm}^{-1}$ and were found as 0.04, 0.04, $0.04-0.04,0.04,0.04 \mathrm{~kg} \mathrm{~mm}^{-1}$ for 2010 year from V75FYR, V50FYR, V25FYR and VFYR $_{75}, V_{F Y R}, V_{5 F}$, treatments, respectively. When WUE and IWUE values were taken into consideration, the maximum WUE and IWUE values were obtained in vegetative and ripening periods and the lowest value was obtained from flowering and yield formation periods. When the results concerning WUE values were in comparison to the findings of different researchers, they were in agreement with those of the other studies (Doorenbos and Kassam, 1979; Chartzoulakis and Drosos, 1999; Gencoglan et al., 2006; Sezen et al., 2006; Demirtas and Ayas, 2009).

The variety of pepper, climate of the region, soil properties and effective use of water also influence yield and quality parameters of pepper. As explained by Davis et al. (2008), it may be attributed to the variety and applied cultural practices handling under different climate and geographical conditions. Crop yield response factor $\left(\mathrm{k}_{\mathrm{y}}\right)$ for 2009 and 2010 year were calculated as 1.29 and 1.24 for pepper, respectively. The specified values of $\mathrm{k}_{\mathrm{y}}(1.29-1.24)$ which is bigger than 1.00 shows that pepper is responsive to the water. The factor of $\mathrm{k}_{\mathrm{y}}$ also matches up with the values obtained by researchers who studied on similar issues (Doorenbos and Kassam, 1979; Sezen et al., 2006; Demirtas and Ayas, 2009).

\section{Conclusion}

According to the results of the study, irrigation water were applied 744 and $750 \mathrm{~mm}$ in $\mathrm{V}_{100} \mathrm{~F}_{100} \mathrm{Y}_{100} \mathrm{R}_{100}$ treatment applied of full irrigation in 2009 and 2010 years. The plant water consumption of pepper was determined as $320-760 \mathrm{~mm}$ and $330-770 \mathrm{~mm}$ for $\mathrm{V}_{0} \mathrm{~F}_{0} \mathrm{Y}_{0} \mathrm{R}_{0}$ treatment 2009 and 2010 years.

The factors of $\mathrm{k}_{\mathrm{y}}$ for the different irrigation levels $\left(V_{100} F_{100} Y_{100} R_{100}, \quad V_{75} F Y R, \quad V_{50} F Y R, \quad V_{25} F Y R, \quad V F_{75} Y R\right.$, $V F_{50} Y R, \quad V F_{25} Y R, \quad V F Y_{75} R, \quad V F Y_{50} R, \quad V F Y_{25} R, \quad V F Y R_{75}$, $V F Y R_{50}, V F Y R_{25}, V_{0} F_{0} Y_{0} R_{0}$ treatments) in 2009 and 2010 years were calculated as 1.29 and 1.24 for pepper, respectively. The factors of $\mathrm{k}_{\mathrm{y}}(1,29$ and 1.24) values are bigger than 1,00 showed that the pepper was susceptible to water. The crop yield response factors $\left(\mathrm{k}_{\mathrm{y}}\right)$ were close to each other in both years of the study. The highest yield decreases in all treatments were in $V_{0} F_{0} Y_{0} R_{0}$ treatments, while the lowest yield decreases were in $V_{100} F_{100} Y_{100} R_{100}$ treatments. In our trial, it was studied out that irrigation treatments considerable influences yield, fruit diameter, weight, length and dry matter ratio.

In this study, it was studied out that irrigation applications considerably influences yield, fruit weight, diameter, length and dry matter. In both years of the study, the highest yield were $26.2 \mathrm{t} \mathrm{h}^{-1}$ and $27.8 \mathrm{t} \mathrm{h}^{-1}$ and it was observed in $\mathrm{V}_{100} \mathrm{~F}_{100} \mathrm{Y}_{100} \mathrm{R}_{100}$ treatment. The lowest yield were observed as $0.2 \mathrm{t} \mathrm{h}^{-1}$ and $0.3 \mathrm{t} \mathrm{h}^{-1}$ in $\mathrm{V}_{0} \mathrm{~F}_{0} \mathrm{Y}_{0} \mathrm{R}_{0}$ treatment. Yield decreased considerably as a result of the diminishment in the water amount. Relative yield decreases in the irrigation treatments in 2009 and 2010 were $2.8 \%, 8.7 \%, 10.6 \%, 12.5 \%, 14.4 \%, 19.1 \%, 20.2 \%$, $24.8 \%, 30.4 \%, 0.8 \%, 1.6 \%, 2.8 \%, 13000.0 \%$ and $7.3 \%$, $9.0 \%, 11.2 \%, 14.9 \%, 15.8 \%, 17.8 \%, 18.3 \%, 21.4 \%$, $25.2 \%, 1.1 \%, 2.2 \%, 3.0 \%, 9166.7 \%$, respectively. WUE and IWUE values of vegetative and ripening periods were the maximum of all the treatments.

As a result, of a possible deficit irrigation in a semihumid climate condition, it is necessary to plan carefully and it is possible to say that the levels and times of the deficit irrigation were significantly effective on pepper yield. It is very important to give sap after planting seedlings. Because of the moisture level in the soil was fulfilled to the field capacity before planting the seedlings, there was no need to apply sap after planting. If deficit irrigation treatment is obligatory, water deficiency should be planned only for vegetative and ripening periods of pepper. The deficit irrigation should not be applied in flowering and yield formation periods and full irrigations should be exactly applied during these periods. In addition, in the irrigation planning to be applied in similar climatic conditions may be benefited from crop yield response factor (ky) values. The results used to determine the amount of reduction in yield in response to the water deficiency applied to the plant may be used in studies related to pepper. It can be recommended that ripening and vegetative periods is most suitable periods for the deficit irrigation practices for pepper irrigation by drip irrigation.

\section{References}

Anonymous. 2005. The Annual Report of Meteorological Station, Bursa, Turkey. www.mgm.gov.tr/verideğerlendirme/il-veilceler-istatistic.aspx?k

Anonymous. 2011a. The Annual Report of Meteorological Station, Bursa, Turkey. www.mgm.gov.tr/verideğerlendirme /il-ve-ilceler-istatistic.aspx?k

Anonymous. 2011b. The Meteorological Station of Greenhouse Application Area, Yenişehir-Bursa, Turkey. www.mgm.gov.tr /verideğerlendirme/il-ve-ilceler-istatistic.aspx?k

Anonymous. 2016. www.tarimorman.gov.tr/Issues/VegetativeProduction.

Ashraf SO, Ewees MSA. 2008. The possible use of humic acid incorporated with drip irrigation system to alleviate the harmful effects of saline water on tomato plants. - Fayoum J. Agric. Res. \& Dev. 22(1).

Bar-Yosef B, Sagiv B. 1982. Response of tomatoes to N and water applied via a trickle irrigation system. II Water. Argon. J., 74: 637-639. 
Bogle CR, Hartz TK, Nuntoez C. 1989. Comparison of subsurface trickle and furrow irrigation on plastic mulched and bare soil for tomato production. J. Am. Soc. Hortic. Sci., 114: 40-43.

Bos MG. 1980. Irrigation efficiencies at crop production level. ICID Bull.29: 18-25.

Braga MB, Klar AE. 2003. Plastic tunell orientation and irrigation management of pepper (Capsicum annuum L.). Irriga, Botucatu, v. 8, n. 1, p. 69-77.

Büyükcangaz H, Demirtas C, Yazgan S, Korukcu A. 2007. Efficient water use in agriculture in Turkey: The need for pressurized irrigation systems, Water International, 32:sup1, 776-785

Cakmak B, Gökalp Z. 2011. Climate change and effective water utilization. Journal of Agricultural Sciences Research. 4(1): 87-95.

Chartzoulakis K, Drosos N. 1999. Irrigation requirements of greenhouse vegetables in crete. Cahiers Options Méditerranéennes, 31: 215-221.

Clough GH, Locasio SJ, Olsen SM 1990. The yield of successively cropped polyethylene mulched vegetables as affected by irrigation method and fertilization management. J. Am. Soc. Hortic. Sci. 115: 884-887.

Davis AR, Webber CL, Perkins-Veazie P, Ruso V, Lopez Galarza S, Sakata Y. 2008. A Review of production systems on watermelon quality. Roceedings of the IXth EUCARPIA Meeting on 98 Genetics and Breeding of Cucurbitaceae (M. PITRAT, editor), INRA, Avignon, France, 515-520.

Demirtas C and Ayas S. 2009. Deficit irrigation effects on pepper (Capsicum annuum L. Demre) yield in unheated greenhouse condition. Journal of Food, Agriculture \& Environment, 7 (3\&4): 989 - 993.

Doorenbos J, Kassam AH. 1979. Yield response to water. FAO Irrigation and Drainage Paper No. 33, Rome.

FAOSTAT. 2016. Food and Agriculture Organization Corporate Statistical Database. http://www.fao.org/faostat/en/\#data/QC

Gencoglan C, Gencoglan S, Akbay C, Boz I. 2006. Deficit irrigation analysis of red pepper (Capsicum annum L.) using the mathematical optimisation method. Turk J. Agric 30: 2033-212.

Goldberg D and Shmueli M. 1971. Emergence, early growth and salinity of five vegetable crops germinated by sprinkle and trickle irrigation in arid zone. Hort. Sci. 6 (6): 559-562.

Gul A, Tuzel Y, Tuzel IH, Irget ME, Kidoglu F, Tepecik M. 2011. Effects of nutrition and irrigation on sweet pepper production in volcanic tuff. Spanish Journal of Agricultural Research, 9 (1): 221-229.
Güngör Y, Yıldırım O. 1989. Tarla Sulama Sistemleri. Ankara Üniversitesi Ziraat Fakültesi Yayınları No. 1155. 371s. Ankara, Turkey.

Hartz TK. 1993. Drip irrigation scheduling for fresh market tomato production. Hort. Science, 28: 35-37.

Howell TA, Yazar A, Scheneider AD, Dusek DA, Copeland KS. 1995. Yield and water use efficiency of corn in response to LEPA irrigation. Transaction of ASAE, Vol. 38 (6) 17371747.

McNeish CM, Welch NC, Nelson RD 1985. Trickle irrigation requirements for stawberries in coastal California. J. Am. Soc. Hortic. Sci. 110: 714-718.

Posgay E. 1972. Proc. 5th Inter. Collogium on Plastics in Agriculture. Budapest, Hungary,

June Proceeding, 2: 888-892.

Ritchie JT, Johnson BS. 1990. Irrigation of agricultural crops. Agronomy Monograph, No 30: 363-390.

Sezen SM. 2005. Effects of drip irrigation management on yield and quality of field grown green beans. Agricultural Water Management, 71: 243-255.

Sezen SM, Yazar A, Eker S. 2006. Effects of drip irrigation regimes on yield and quality of field grown bell pepper. Agricultural Water Management, 81: 115-131.

Smittle DA, Dickens WL, Stansell JR. 1994. Irrigation regimes affect yield and water use by bell pepper. American Society for Horticultural Science, V. 119 (5): 936-939.

Steel RGD, Torrie JH. 1980. Principles and procedures of statistics. A biometrical approach. McGraw-Hill, NewYork, pp.186-187.

Stewart JI, Misra RD, Pruitt WO, Hagan RM. 1975. Irrigating corn and sorghum with a deficient water supply. Trans. ASAE, 18: 270-280.

Van Straten G, Van Willingenburg G, Van Henten E, Van Ooteghem R. 2010. Optimum control of greenhouse cultivation. CRC Press, USA p.305.

Vural H, Eşiyok D, Duman İ. 2000. Culture Vegetables (Grow Vegetable). Horticulture Department, Faculty of Agriculture, Ege University, Bornova-İzmir, 440.

Yuan BZ, Sun J, Nishiyama S. 2003. Effect of drip irrigation on strawberry growth inside a plastic greenhouse. Biosystems Engineering, 87 (2): 237- 245.

Zhang H, Wang X, You M, Liu C. 1999. Water-yield relations and water-use efficiency of winter wheat in the North China Plain. Irrigation Science, v.19, p.37-45. 